\title{
STUDIES ON ANTAGONISM BETWEEN HUMAN SKIN BACTERIA
}

\author{
P. D. MARSH* AND S. SELWYN \\ Department of Bacteriology, Westminster Medical School, London SWIP 2AR
}

\section{Plate X}

BECA USE mixed cultures are the rule in natural environments and pure cultures are the exception, we have become increasingly interested in interactions among bacteria, notably those that occur on the human skin. Selwyn and Ellis (1972) examined primary skin cultures from 1,320 individuals and found 173 strains belonging to the Micrococcaceae that possessed antibacterial activity. Detailed investigations have subsequently been carried out on a particularly active and stable strain of Staphylococcus epidermidis of biotype 4 isolated from one of us. This organism has a relatively broad spectrum of antibacterial activity due to the production of a polypeptide antibiotic of low molecular weight (Selwyn, Marsh and Sethna, 1976).

In the present paper, the results of growing the antibiotic-producing staphylococcus in mixed culture with other bacteria are compared with those obtained with a similar strain of staphylococcus that did not produce antibiotic. The studies were performed semi-quantitatively on solid media and quantitatively in liquid media.

\section{MATERIALS AND METHODS}

Bacterial strains. The antibiotic-producing strain of Staph. epidermidis classified as Staphylococcus biotype 4 (Baird Parker, 1974) and referred to as $\mathrm{S6}^{+}$was isolated from the forehead of one of us (S. S.). The non-antibiotic-producing strain of Staph. epidermidis biotype $4\left(\mathrm{S6}^{-}\right)$was isolated from the same area. All other strains were isolated from recent clinical specimens, except for Corynebacterium diphtheriae var. gravis which was a stock culture. The micrococcus strain M7 was classified as Micrococcus biotype 7 (Baird-Parker, 1965) and the group-D diphtheroid according to Evans (1968). All other strains were classified by the system of Cowan and Steel (1965), and are shown in table I.

Semi-quantitative studies. The following two methods were used for studying bacterial antagonism semiquantitatively on solid medium. (1) Direct antagonism. Approximately $10^{6}$ colony-forming units (c.f.u.) of strain $\mathrm{S}^{+}{ }^{+}$were spot-inoculated on to the surface of a plate seeded with approximately $10^{6}$ c.f.u. of a background strain, and both organisms were allowed to grow simultaneously for $18 \mathrm{~h}$. (2) Deferred antagonism. Strain S6 ${ }^{+}$was inoculated as a line across a plate and incubated for $24 \mathrm{~h}$. Bacterial growth was removed, and the remaining bacteria were killed by exposure to chloroform vapour. The test strains were inoculated at

\section{Received 28 June 1976; accepted 31 Aug. 1976}

* Present address: Medical Research Council Dental Epidemiology Unit, The London Hospital Medical College, London E1 2AD.

J. MED. MICROBIOL.—VOL. 10 (1977) 
TABLE I

Direct and deferred antagonism between Staphylococcus $\mathrm{S6}^{+}$and other bacteria

\begin{tabular}{|c|c|c|c|}
\hline \multirow{2}{*}{ Background organism } & \multirow{2}{*}{ Medium } & \multicolumn{2}{|c|}{ inhibition zones $(\mathrm{mm})$} \\
\hline & & Direct & Deferred \\
\hline $\begin{array}{l}\text { Staphylococcus epidermidis, strain } \mathrm{S}^{-} \\
\text {Micrococcus sp., strain } \mathrm{M} 7 \\
\text { Staph. aureus } \\
\text { Staph. aureus* } \\
\text { Streptococcus pyogenes } \\
\text { Viridans streptococcus } \\
\text { Strep. pneumoniae type } 3 \\
\text { Faecal streptococcus } \\
\text { Clostridium welchii } \\
\text { Group-D diphtheroid } \\
\text { Corynebacterium diphtheriae var. gravis } \\
\text { C. diphtheriae var. intermedius } \\
\text { Neisseria catarrhalis } \\
\text { N. gonorrhoeae } \\
\text { Pasteurella septica } \\
\text { Haemophilus influenzae } \\
\text { Proteus mirabilis } \\
\text { Pseudomonas aeruginosa } \\
\text { Escherichia coli } \\
\text { Klebsiella pneumoniae }\end{array}$ & $\begin{array}{l}\text { NA } \\
\text { NA } \\
\text { NA } \\
\text { NA } \\
\text { BA } \\
\text { BA } \\
\text { BA } \\
\text { BA } \\
\text { BA } \\
\text { NA } \\
\text { NA } \\
\text { NA } \\
\text { NA } \\
\text { CA } \\
\text { NA } \\
\text { CA } \\
\text { NA } \\
\text { NA } \\
\text { NA } \\
\text { NA }\end{array}$ & $\begin{array}{r}0 \\
7 \\
5 \\
3 \\
5 \\
4 \\
4 \\
1 \\
3 \\
10 \\
3 \\
4 \\
2 \\
0 \\
4 \\
0 \\
0 \\
0 \\
0 \\
0\end{array}$ & $\begin{array}{r}0 \\
25 \\
21 \\
18 \\
20 \\
\ldots \\
\ldots \\
\ldots \\
\ldots \\
33 \\
\dddot{20} \\
\dddot{24} \\
\dddot{17} \\
0 \\
0 \\
\ldots\end{array}$ \\
\hline
\end{tabular}

$\mathrm{NA}=$ nutrient agar $; \mathrm{BA}=$ blood agar; $\mathrm{CA}=$ chocolate agar

$\ldots=$ not tested.

* $\dddot{T}$ This strain was resistant to penicillin, tetracycline, erythromycin, methicillin, gentamicin, fusidic acid, lincomycin and chloramphenicol.

right angles to the line of original growth and the plate was reincubated for $18 \mathrm{~h}$. In both methods, zones of inhibition were recorded as shown in table $I$.

Replicate plates were made of cultures with inhibition zones to assess the extent of bactericidal and bacteristatic activity. The timing of antibiotic production was determined by removing the growth of the " producer" organism after varying intervals in the deferred test, and by using time-lapse photomicrography to study the development of inhibition zones in direct antagonism tests (Marsh, 1975). Antibiotic production by strain $\mathrm{S}^{+}{ }^{+}$was detected against suitable indicator strains under a variety of conditions aerobically and anaerobically and on different media including nutrient agar with $\mathrm{NaCl} 5 \% \mathrm{w} / \mathrm{v}$, Tween $800.5 \% \mathrm{w} / \mathrm{v}$, or oleic acid $1.0 \% \mathrm{v} / \mathrm{v}$. All the standard media listed in tables I and II were prepared as described by Cruickshank (1965).

Quantitative studies. Antagonism was investigated quantitatively by the use of pure and mixed liquid batch-cultures. Viable counts were determined on selective media by the method of Miles, Misra and Irwin (1938). The combinations of bacteria with their appropriate growth and selective media are shown in table II. Glucose broth consisted of nutrient broth with the addition of glucose $0.5 \% \mathrm{w} / \mathrm{v}$; serum broth consisted of nutrient broth with the addition of horse serum $10 \% \mathrm{v} / \mathrm{v}$; serum broth plus catalase consisted of serum broth with the addition of 100 enzyme units per ml of catalase (British Drug Houses, Ltd) in $0 \cdot 2 \mathrm{M}$ phosphate buffer at $p \mathrm{H}$ 7.0. Selective media were developed according to the antibioticsensitivity patterns and MICs of particular antibiotics for the relevant bacteria (Marsh, 1975).

Batch cultures were incubated aerobically at $33^{\circ} \mathrm{C}$ in $150-\mathrm{ml}$ conical flasks stirred magnetically. The appropriate culture fluids in $20 \mathrm{ml}$ quantities were inoculated with $0.1 \mathrm{ml}$ of various dilutions of overnight cultures of the required bacterial strains. Viable counts were 
TABLE II

Viable counts in mixed batch cultures

\begin{tabular}{|c|c|c|c|c|}
\hline \multirow{2}{*}{$\begin{array}{l}\text { Mixed cultures } \\
\text { (strain number } \\
\text { or designation) }\end{array}$} & \multirow{2}{*}{$\begin{array}{l}\text { Growth } \\
\text { medium }\end{array}$} & \multirow{2}{*}{$\begin{array}{l}\text { Selective } \\
\text { medium }\end{array}$} & \multicolumn{2}{|c|}{$\begin{array}{l}\text { Log. viable count } \\
\text { (c.f.u. per ml) at }\end{array}$} \\
\hline & & & $12 \mathrm{~h}$ & $30 \mathrm{~h}$ \\
\hline $\begin{array}{l}\mathbf{S 6} 6^{+} \\
\mathbf{S 6} 6^{-}\end{array}$ & NB & $\begin{array}{l}\mathbf{N A}+\mathbf{F A} \\
\mathbf{N A}+\mathbf{P}\end{array}$ & $\begin{array}{l}8 \cdot 7 \\
7 \cdot 2\end{array}$ & $\begin{array}{l}8 \cdot 6 \\
8 \cdot 3\end{array}$ \\
\hline $\begin{array}{l}\mathbf{S 6}^{+} \\
\mathbf{M}^{+}\end{array}$ & NB & $\begin{array}{l}\mathbf{N A}+\mathbf{B} \\
\mathbf{N A}+\mathbf{F}\end{array}$ & $\begin{array}{l}6 \cdot 4 \\
6 \cdot 3\end{array}$ & $\begin{array}{l}8 \cdot 2 \\
5 \cdot 6\end{array}$ \\
\hline $\begin{array}{l}\mathrm{S6}^{-} \\
\mathrm{M7}\end{array}$ & NB & $\begin{array}{l}\mathrm{NA}+\mathrm{B} \\
\mathrm{NA}+\mathrm{F}\end{array}$ & $\begin{array}{l}7.2 \\
7 \cdot 1\end{array}$ & $\begin{array}{l}7 \cdot 9 \\
8 \cdot 0\end{array}$ \\
\hline $\begin{array}{l}\text { S6+ } \\
\text { Group-D diphtheroid }\end{array}$ & NB & $\begin{array}{l}\mathrm{NA}+\mathrm{B} \\
\mathrm{NA}+\mathrm{F}\end{array}$ & $\begin{array}{l}6 \cdot 6 \\
3 \cdot 6\end{array}$ & $\begin{array}{c}8.5 \\
0\end{array}$ \\
\hline $\begin{array}{l}\text { S6- } \\
\text { Group-D diphtheroid }\end{array}$ & NB & $\begin{array}{l}\mathrm{NA}+\mathrm{P} \\
\mathrm{NA}+\mathrm{F}\end{array}$ & $\begin{array}{l}8 \cdot 3 \\
5 \cdot 4\end{array}$ & $\begin{array}{l}8 \cdot 6 \\
6 \cdot 0\end{array}$ \\
\hline $\begin{array}{l}\mathrm{S6}^{+} \\
\text {C. diphtheriae var gravis }\end{array}$ & NB & $\begin{array}{l}\mathrm{NA}+\mathrm{B} \\
\text { Tellurite }\end{array}$ & $\begin{array}{l}5.0 \\
5 \cdot 1\end{array}$ & $\begin{array}{l}7 \cdot 6 \\
7 \cdot 1\end{array}$ \\
\hline $\begin{array}{l}\text { S6+ } \\
\text { Viridans streptococcus }\end{array}$ & GB & $\underset{\mathbf{B A}+\mathbf{C V}}{\text { MacConkey }}$ & $\begin{array}{l}8 \cdot 5 \\
7 \cdot 5\end{array}$ & $\begin{array}{l}8 \cdot 8 \\
8 \cdot 4\end{array}$ \\
\hline $\begin{array}{l}\mathrm{S6}^{+} \\
\text {Faecal streptococcus }\end{array}$ & GB & $\begin{array}{l}\mathbf{N A}+\mathbf{F} \\
\mathbf{B A}+\mathbf{C V}\end{array}$ & $\begin{array}{l}9 \cdot 3 \\
9 \cdot 3\end{array}$ & $\begin{array}{l}8 \cdot 9 \\
8 \cdot 8\end{array}$ \\
\hline $\begin{array}{l}\mathrm{S6}^{+} \\
\text {Streptococcus pmeumoniae }\end{array}$ & SB & $\underset{B A+C V}{\text { MacConkey }}$ & $\begin{array}{l}4 \cdot 0 \\
8 \cdot 3\end{array}$ & $\begin{array}{c}0 \\
6 \cdot 3\end{array}$ \\
\hline $\begin{array}{l}\text { S6- } \\
\text { Strep. pneumoniae }\end{array}$ & SB & $\begin{array}{l}\mathbf{N A}+\mathbf{P} \\
\mathbf{B A}+\mathbf{C V}\end{array}$ & $\begin{array}{l}6.0 \\
8.8\end{array}$ & $\underset{6}{0}$ \\
\hline $\begin{array}{l}\text { S6 } \\
\text { Strep. pneumoniae } \\
\quad \text { (inoculated after } 4 \text { h) }\end{array}$ & SB & $\begin{array}{l}\text { MacConkey } \\
\text { BA }+ \text { CV }\end{array}$ & $\begin{array}{l}7 \cdot 5 \\
8 \cdot 1\end{array}$ & $\begin{array}{l}7.9 \\
8.3\end{array}$ \\
\hline $\begin{array}{l}\text { S6- } \\
\text { Strep. pneumoniae } \\
\quad \text { (inoculated after } 4 \text { h) }\end{array}$ & SB & $\begin{array}{l}\mathbf{N A}+\mathbf{P} \\
\mathbf{B A}+\mathbf{C V}\end{array}$ & $\begin{array}{l}7 \cdot 5 \\
8 \cdot 2\end{array}$ & $\begin{array}{l}7 \cdot 5 \\
8 \cdot 5\end{array}$ \\
\hline $\begin{array}{l}\text { S6 } \\
\text { Strep. pneumoniae }\end{array}$ & $\mathbf{S B}+$ catalase & $\underset{B A+C V}{\text { MacConkey }}$ & $\begin{array}{l}7 \cdot 0 \\
7 \cdot 6\end{array}$ & $\begin{array}{l}7 \cdot 3 \\
7 \cdot 3\end{array}$ \\
\hline $\begin{array}{l}\mathrm{S6}^{-} \\
\text {Strep. pneumoniae }\end{array}$ & SB +catalase & $\begin{array}{l}\mathbf{N A}+\mathbf{P} \\
\mathbf{B A}+\mathbf{C V}\end{array}$ & $\begin{array}{l}6 \cdot 3 \\
8 \cdot 2\end{array}$ & $\begin{array}{l}6 \cdot 5 \\
8 \cdot 1\end{array}$ \\
\hline $\begin{array}{l}\text { S6+ } \\
\text { Strep. pyogenes }\end{array}$ & SB & $\begin{array}{c}\text { MacConkey } \\
\text { BA }+\mathbf{C V}\end{array}$ & $\begin{array}{l}8 \cdot 7 \\
7 \cdot 0\end{array}$ & $\begin{array}{l}7.9 \\
6 \cdot 9\end{array}$ \\
\hline $\begin{array}{l}\text { S6- } \\
\text { Strep. pyogenes }\end{array}$ & SB & $\underset{\mathbf{B A}+\mathbf{C V}}{\text { MacConkey }}$ & $\begin{array}{l}6 \cdot 1 \\
8 \cdot 7\end{array}$ & $\begin{array}{l}4 \cdot 4 \\
8 \cdot 0\end{array}$ \\
\hline $\begin{array}{l}\mathrm{S}^{+} \\
N . \text { catarrhalis }\end{array}$ & GB & $\begin{array}{l}\mathrm{NA}+\mathrm{B} \\
\mathrm{NA}+\mathrm{T}\end{array}$ & $\begin{array}{l}7 \cdot 3 \\
7 \cdot 9\end{array}$ & $\begin{array}{l}6 \cdot 9 \\
8 \cdot 0\end{array}$ \\
\hline $\begin{array}{l}\text { S6- } \\
\text { N. catarrhalis }\end{array}$ & GB & $\begin{array}{l}\mathbf{N A}+\mathbf{P} \\
\mathbf{N A}+\mathbf{T}\end{array}$ & $\begin{array}{l}6 \cdot 8 \\
8 \cdot 2\end{array}$ & $\begin{array}{l}5 \cdot 8 \\
7 \cdot 1\end{array}$ \\
\hline $\begin{array}{l}\text { Staphylococcus aureus } \\
\text { with } \mathbf{S 6}^{+} \\
\text {with } \mathbf{S} 6^{-} \\
\text {with } \mathbf{M} 7 \\
\text { with group-D diphtheroid }\end{array}$ & NB & PPA & $\begin{array}{l}8 \cdot 4 \\
7 \cdot 4 \\
6 \cdot 8 \\
5 \cdot 8 \\
5 \cdot 1\end{array}$ & $\begin{array}{l}7 \cdot 3 \\
7 \cdot 1 \\
6 \cdot 3 \\
6 \cdot 3 \\
5 \cdot 6\end{array}$ \\
\hline
\end{tabular}

c.f.u. $=$ Colony-forming units.

$\mathrm{NB}=$ Nutrient broth; $\mathrm{GB}=$ glucose broth; $\mathrm{SB}=$ serum broth; $\mathrm{SB}+$ catalase $=$ serum broth +100 units of catalase per $\mathrm{ml}$ in $0.2 \mathrm{M}$ phosphate buffer, $p \mathrm{H} \mathrm{7.0;} \mathrm{NA}+\mathrm{FA}=$ nutrient agar + fusidic acid $0.196 \mu \mathrm{g}$ per ml; NA+P $=$ nutrient agar + penicillin $0 \cdot 1 \mu \mathrm{g}$ per $\mathrm{ml}$; $\mathrm{NA}+\mathrm{B}=$ nutrient agar + bacitracin $0 \cdot 1$ unit per $\mathrm{ml}$; $\mathrm{NA}+\mathrm{F}=$ nutrient agar + furazolidone $7.5 \mu \mathrm{g}$ per $\mathrm{ml}$; $\mathrm{NA}+\mathrm{T}=$ nutrient agar + trimethoprim $15.0 \mu \mathrm{g}$ per $\mathrm{ml} ; \mathbf{B A}+\mathbf{C V}=$ blood agar + crystal violet 1 in $666666(\mathrm{w} / \mathrm{v}) ; \mathrm{PPA}=$ phenolphthalein-phosphate agar. 
taken after $0,4,8,12$ and $30 \mathrm{~h}$ and growth curves were constructed. Strains were grown initially in pure cultures, and then under similar conditions in mixed cultures.

The timing of antibiotic production in liquid medium was determined by growing pure cultures of strain $\mathrm{S}^{+}$in nutrient broth. Culture samples of $1 \mathrm{ml}$ were taken at hourly intervals, bacteria were removed by centrifugation and Millipore filtration (average pore diameter $0.45 \mu \mathrm{m}$ ), and the supernate was spotted on to plates seeded with a sensitive indicator organism (M7). After incubation, zones of inhibition were measured.

\section{RESULTS}

\section{Semi-quantitative studies}

In direct antagonism tests, strain $\mathrm{S}^{+}{ }^{+}$was active against all gram-positive strains tested-with the notable exception of strain $\mathrm{S6}^{-}$, which had been derived originally from the same skin area. There was, however, only limited activity against gram-negative bacteria (table I). In a control experiment, strain $\mathrm{S6}^{-}$had no antibacterial activity against any of the test strains. In deferred antagonism tests, strain $\mathrm{S6}^{+}$had a broader spectrum of activity and also produced larger zones than in direct antagonism procedures. Replicate plating of inhibition zones produced by strain $\mathrm{S}^{+}$indicated that the antibiotic has a bactericidal mode of action. No colonies of the test strains grew in the replicated inhibition zones, except at the periphery.

Direct antagonism viewed under a plate microscope was evident within $2 \mathrm{~h}$ of culture and was well developed by $4 \mathrm{~h}$ (fig. $1 a$ ). Subsequent growth by the background test strain served only to emphasise this zone of inhibition (fig. $1 b$ ). Deferred antagonism techniques detected inhibition zones after 7 hours' growth of the producer $\mathrm{S6}^{+}$strain. After this threshold period of growth, zone sizes were larger with this method than with direct antagonism. Inhibition zones were detected under aerobic and anaerobic conditions and in the presence of $\mathrm{NaCl} 5 \%$, Tween $800.5 \%$ and oleic acid $1.0 \%$.

\section{Quantitative Studies}

Viable counts of the different mixed cultures at 12 and $30 \mathrm{~h}$ are shown in table II. Mixed batch cultures of strains $\mathrm{S6}^{+}$and $\mathrm{S6}^{-}$did not demonstrate any mutual or unilateral antagonism. Both strains grew as well together in mixed culture as they did in pure culture. Strain $\mathrm{S6}^{-}$did not inhibit the growth of any other strain in batch culture. The only detectable difference between strains $\mathrm{S}^{+}$and $\mathrm{S6}^{-}$was the ability of the former to produce an antibiotic.

With strain S6- $^{-}$, growth of strain M7 reached virtually the same level as when it was grown in pure culture. In contrast, unilateral antagonism of the strain M7 occurred within $11 \mathrm{~h}$ when it was grown in mixed culture with strain $\mathrm{S}^{+}$. After $28 \mathrm{~h}$, the growth of strain M7 was 300-fold less than in pure culture and 200-fold less than in mixed culture with strain $\mathrm{S6}^{-}$.

The viable counts of the group-D diphtheroid in mixed culture with strain S6- were lower than in pure culture, but the diphtheroid remained capable of division and even after incubation for $56 \mathrm{~h}$ it was still slowly increasing in 

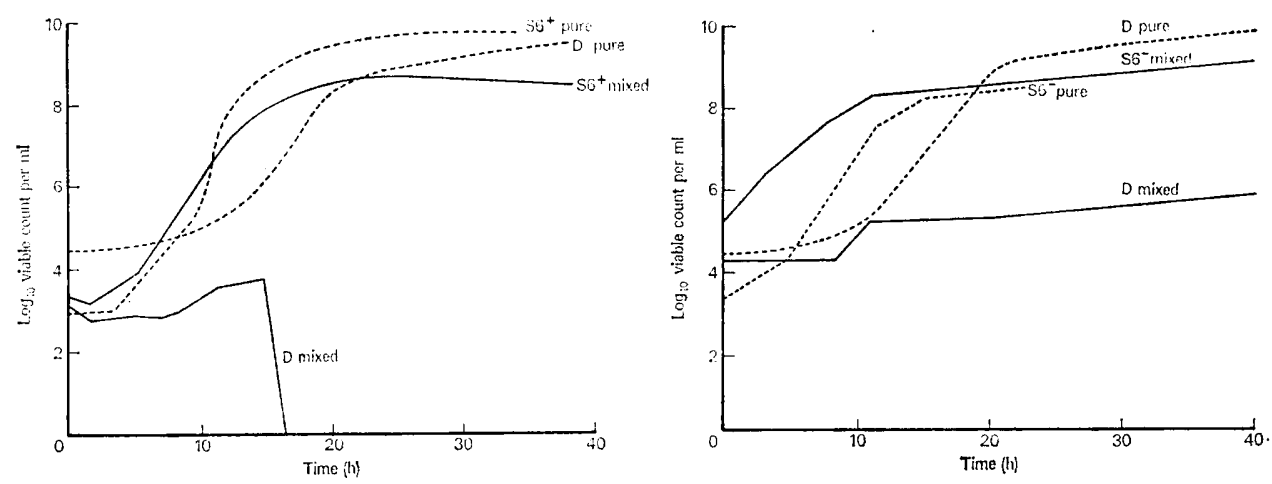

FIG. 2.-Growth curves of mixed batch cultures of $(a)$ strain $\mathrm{S}^{+}$and group-D diphtheroid (D), (b) strain $\mathrm{S6}^{-}$and group-D diphtheroid (D), in nutrient broth at $33^{\circ} \mathrm{C}$.
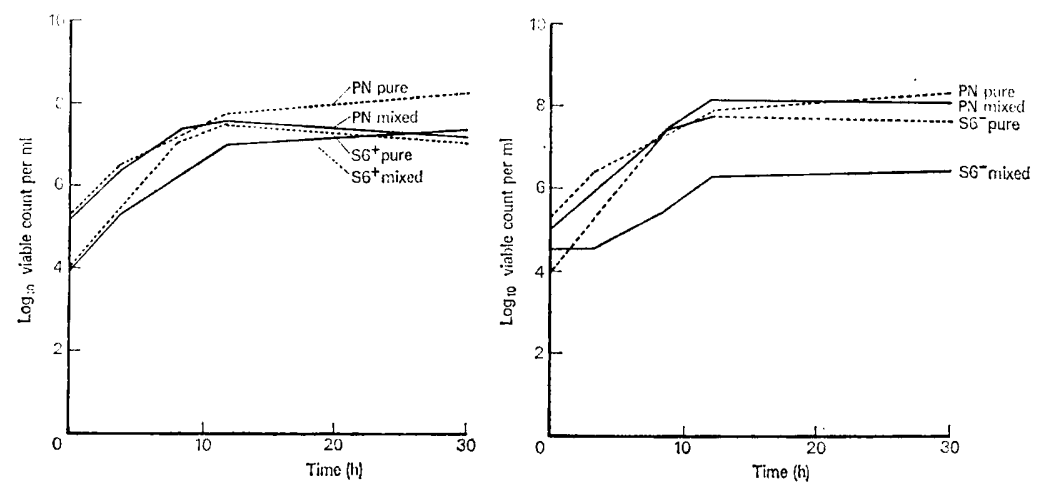

FIG. 3.-Growth curves of mixed batch cultures of (a) strain $\mathrm{S}^{+}$and Streptococcus pneumoniae (PN), (b) strain $\mathrm{S6}^{-}$and Strep. pneumoniae (PN), in serum broth plus 100 units per $\mathrm{ml}$ of catalase (in $0.2 \mathrm{M}$ phosphate buffer, $p \mathrm{H} 7 \cdot 0$ ) at $33^{\circ} \mathrm{C}$.
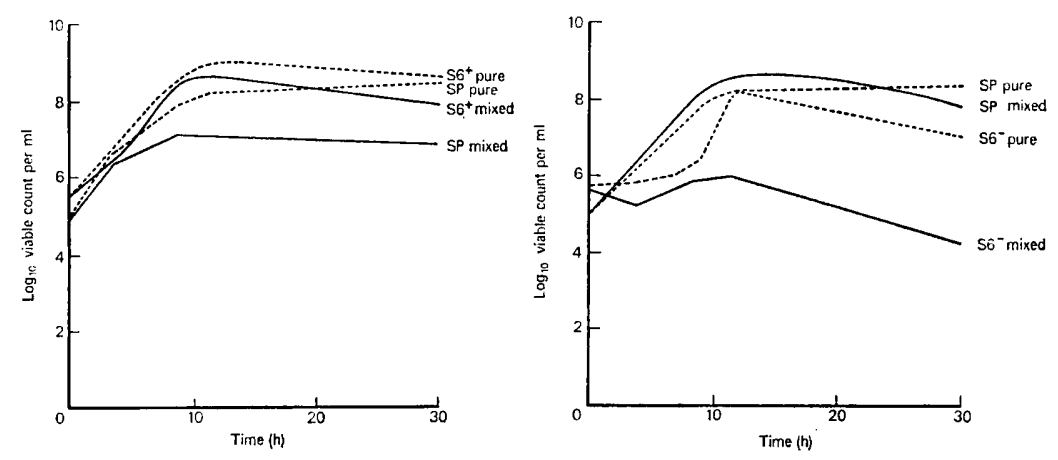

FIG. 4.-Growth curves of mixed batch cultures of (a) strain $\mathrm{S}^{+}$and Strep. pyogenes (SP), (b) strain $\mathrm{S6}^{-}$and Strep. pyogenes (SP) in serum broth at $33^{\circ} \mathrm{C}$. 
viable count (fig. $2 b$ ). However, in mixed culture with strain $\mathrm{S}^{+}$the viable count of the group-D diphtheroid fell below the detectable level of the counting method after $16 \mathrm{~h}$ (fig. $2 a$ ). The diphtheroid was still not detected when whole plates of selective media were flooded with culture fluid. In liquid medium, strain $\mathrm{S}^{+}$did not inhibit the growth of $C$. diphtheriae var. gravis.

In separate experiments, strain $\mathrm{S}^{+}$was grown with two strains of viridans streptococci with different results. In one mixed culture, the two strains grew together without any interaction; in the other, strain $\mathrm{S}^{+}$was markedly inhibited over the final $6 \mathrm{~h}$ of growth. Similarly, when strain $\mathrm{S}^{+}$was grown with two strains of faecal streptococci in separate experiments, two different results were obtained. No interaction was detected with one strain, but with the other the viable counts of strain $\mathrm{S}^{+}$after $29 \mathrm{~h}$ were 100 -fold lower than in pure culture.

In serum broth, Strep. pneumoniae type 3 was partially inhibited by strains $\mathrm{S}^{+}$and $\mathrm{S6}^{-}$, whereas the two staphylococci were completely inhibited by the pneumococcus in mixed culture in glucose broth. Although the $p \mathrm{H}$ fell, it did not reach inhibitory levels. When the experiment was repeated in serum broth, but with the pneumococcus inoculated after $4 \mathrm{~h}$, both strains $\mathrm{S}^{+}$and $\mathrm{S6}^{-}$were able to grow to levels approaching those in pure culture. When serum broth supplemented with catalase was used as the growth medium for the same mixed cultures, strain $\mathrm{S}^{+}$was unaffected by the pneumococcus and was able to inhibit the latter eight-fold in comparison with its growth in pure culture (fig. 3a). However, strain S6- was still inhibited five-fold (fig. 3b). Figs. $4 a$ and $4 b$ show the mixed-culture results of strain $\mathrm{S}^{+}$and strain $\mathrm{S}^{-}$ with Strep. pyogenes. Strain $\mathrm{S}^{+}$inhibited the streptococcus almost 50 -fold whereas the streptococcus inhibited strain S6- 500-fold in comparison with its growth in pure culture. In mixed culture with Neisseria catarrhalis, both strains $\mathrm{S6}^{+}$and $\mathrm{S6}^{-}$showed no antagonistic effect but instead there was a slight reduction in the growth of the staphylococci.

The results of mixed cultures of a non-antibiotic-producing strain of Staph. aureus with the skin commensals were difficult to analyse because a suitable selective medium for the differential counts was not discovered. The M7 and group-D diphtheroid strains were partially inhibited by Staph. aureus, though both strains were still slowly increasing in viable count after $30 \mathrm{~h}$. Strains $\mathrm{S}^{+}$and $\mathrm{S6}^{-}$each grew without marked inhibition when mixed with Staph. aureus, though strain $\mathrm{S6}^{-}$did not reach the population level attained by strain $\mathrm{S6}^{+}$.

Antibiotic production by strain $\mathrm{S}^{+}$in liquid medium was detected after incubation for $13 \mathrm{~h}$ at $33^{\circ} \mathrm{C}$.

\section{Discussion}

The quantitative results from batch cultures confirmed the semi-quantitative findings on solid media that strain $\mathrm{S6}^{+}$had no effect on strain $\mathrm{S6}^{-}$, and that strain $\mathrm{S6}^{-}$did not significantly inhibit any other strain. The only known difference between the two organisms was the ability of strain $\mathrm{S}^{+}$to produce 
ANTAGONISM BETWEEN SKIN BACTERIA

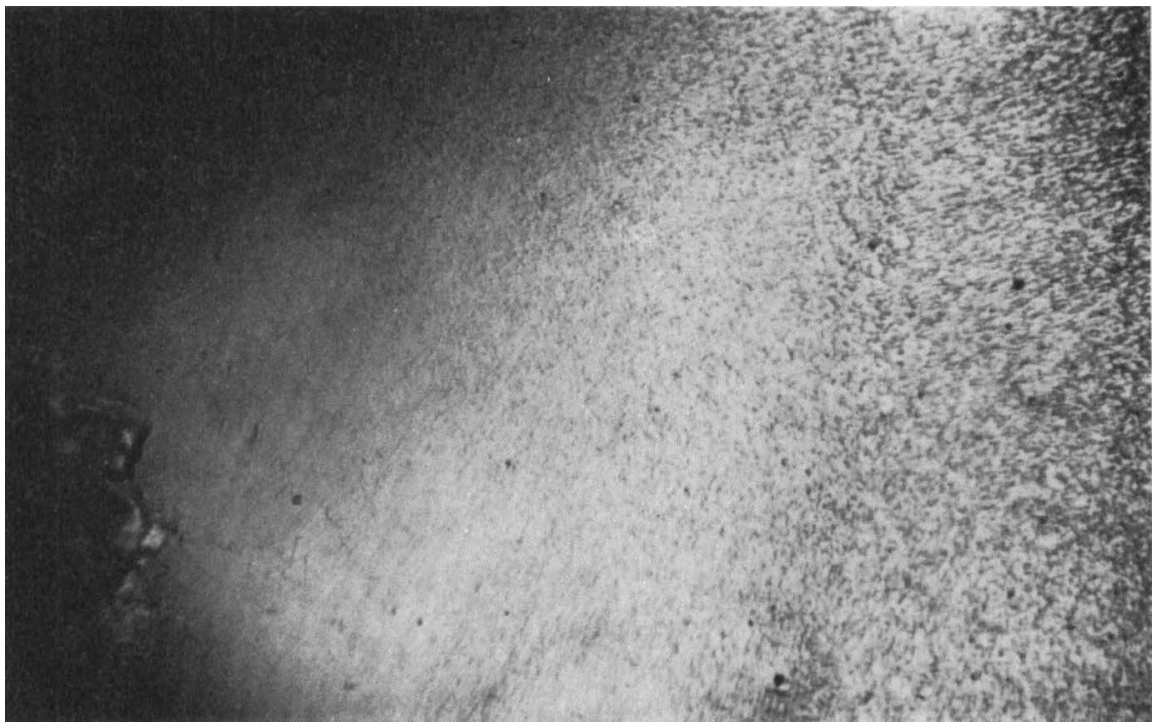

FIG. 1a.-Direct antagonism; inhibition zone after incubation for $3 \frac{1}{2} \mathrm{~h}$; strain $\mathrm{S}^{+}$stab at left, initial background growth of Staphylococcus aureus just visible at right. $\times 12$.

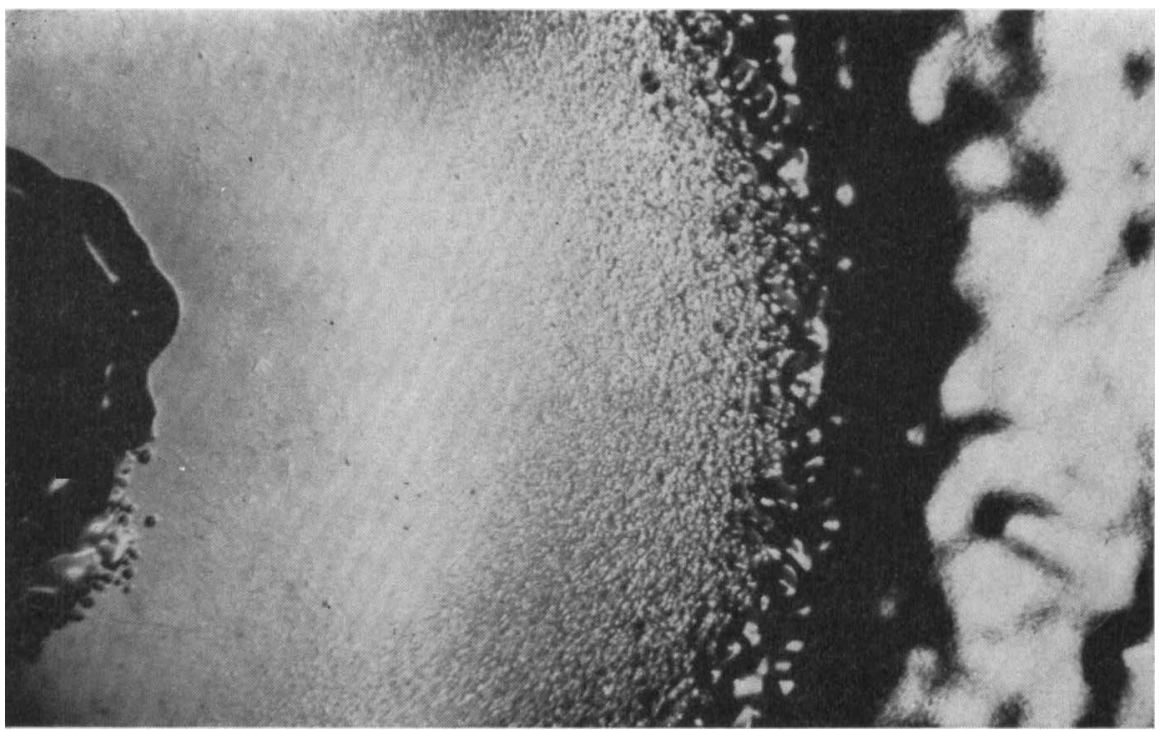

FIG. 1 b. - - The same field as in fig $1 a$ after incubation for $12 \frac{1}{2} \mathrm{~h} . \quad \times 12$. 
an antibiotic. Thus, in the mixed batch-cultures strain $\mathrm{S6}^{-}$acted as a control and any effect in a mixed culture with $\mathrm{S}^{+}$not observed in one with $\mathrm{S6}^{-}$was assumed to be due to antibiotic.

Unilateral antagonism by strain $\mathrm{S}^{+}$was demonstrated in mixed batch cultures against strain M7, the group-D diphtheroid and Strep. pyogenes. In similar mixed cultures, strain $\mathrm{S6}^{-}$had no effect against strain $\mathbf{M} 7$, the growth of the diphtheroid was only slightly slowed by strain $\mathrm{S6}^{-}$, and strain $\mathrm{S6}^{-}$was itself markedly inhibited by Strep. pyogenes. Thus antibiotic production conferred an advantage on strain $\mathrm{S}^{+}+$in these mixed cultures.

Over 50 years ago, McLeod and Gordon (1922) showed that hydrogenperoxide production by a pneumococcus caused its auto-inhibition. This observation was confirmed and extended in the present study of mutual antagonism between a pneumococcus and strain $\mathrm{S}^{+}$in catalase-supplemented broth. Although strain S6- was still slightly inhibited, strain S6+ under the same conditions was able to inhibit the pneumococcus. Similarly, adequate initial catalase production by the staphylococci themselves probably prevented their subsequent inhibition when they were inoculated $4 \mathrm{~h}$ before the pneumococcus, and also prevented auto-inhibition of the pneumococcus in the resulting mixtures.

No antagonism could be detected between strain $\mathrm{S}^{+}$and Staph. aureus in liquid medium, whereas on solid media strain $\mathrm{S}^{+}$powerfully inhibited strains of Staph. aureus (including multiple antibiotic-resistant strains). Discordant results in the two systems were also obtained against $C$. diphtheriae, and the paradoxical inhibition of strain $\mathrm{S}^{+}$in liquid media by some viridans and faecal streptococci, pneumococci and $N$. catarrhalis were presumably due to dilution of the $\mathrm{S6}^{+}$antibiotic to below the bacteristatic level while inhibitory products of the other organisms remained at active concentrations. The effect of dilution was probably also responsible for the fact that there was a longer interval before both unilateral antagonism and antibiotic production could be demonstrated in liquid than on solid media. In the latter, the polypeptide antibiotic diffuses to a certain extent, but concentrations in the neighbourhood of producer colonies are relatively high.

Similarly, the failure to demonstrate in liquid media a uniformly bactericidal effect for the $\mathrm{S}^{+}$antibiotic--except against the extremely sensitive group-D diphtheroid-can be ascribed to dilution. Thus, the high local concentrations in agar can readily reach bactericidal levels, whereas the titres in broth produced by relatively fewer cells dispersed in a large volume of fluid appear usually to attain only bacteristatic levels. Simple tests for antagonism on solid media are therefore sensitive screening procedures before more detailed studies in liquid cultures are undertaken. The latter, however, not only provide quantitative data but also permit more than two organisms to be studied; and they allow insight into the kinetics of inhibition. A longer term study of these interactions has been made in a simple continuous-culture system (Marsh and Selwyn, 1977).

The antibiotic from strain $\mathrm{S}^{+}$was produced under aerobic and anaerobic conditions and in the presence of both $5 \%$ sodium chloride and unsaturated fatty acids. The latter finding contrasts with the narrower spectrum antibiotic 
activity of Staph. aureus type 71 studied by Barrow (1963). Thus the S6+ antibiotic is produced under conditions found on the skin surface and has its greatest activity against the types of bacteria most likely to be encountered there. Production of the antibiotic during the logarithmic growth phase is in contrast with the production of the chemically analogous antibiotics by species of Bacillus, which occurs in the stationary growth phase and is believed to be a factor in repressing vegetative cell functions and promoting sporulation (Sarkar and Paulus, 1972).

The competitive advantage that antibiotic production has been shown to confer on strain $\mathrm{S}^{+}$provides a basis for the results of a recent epidemiological study on the protective effect of similar organisms in skin lesions (Selwyn, 1975). Although strain S6+ itself is antagonistic to few gram-negative bacteria, its semipurified antibiotic has a surprisingly wide antimicrobial spectrum, including action on Pseudomonas spp., and even Candida spp. (Selwyn et al., 1976). The significance of this finding in the natural defence of the skin against colonisation by pathogens has yet to be determined. Certainly the possible accumulation of such antibiotics in the epidermis should be investigated, particularly in skin lesions containing large bacterial populations.

\section{SUMMARY}

Antagonism by an antibiotic-producing Staphylococcus epidermidis strain $\left(\mathrm{S}^{+}\right)$against other bacteria was studied semi-quantitatively on solid media and quantitatively in liquid batch culture. Parallel experiments were performed with a similar but non-antibiotic producing strain $\left(\mathrm{S6}^{-}\right)$. On solid media strain $\mathrm{S}^{+}$in the logarithmic growth phase unilaterally inhibited members of all gram-positive species tested, whereas $\mathrm{S6}^{-}$had no effect. In liquid media, more complex interactions were observed, including mutual and reversed antagonisms. The relevance of these findings to the ecology of human skin is discussed.

P. D. M. was initially supported by a grant from Ethicon Limited and subsequently by one from Beecham Products Limited.

\section{REFERENCES}

Baird-Parker, A. C. 1965. Staphylococci and their classification. Ann. N.Y. Acad. Sci., $128,4$.

Baird-PARKer, A. C. 1974. The basis for the present classification of staphylococci and micrococci. Ann. N.Y. Acad. Sci., 236, 7.

BARRow, G. I. 1963. Microbial antagonism by Staphylococcus aureus. J. gen. Microbiol., 31, 471.

CowAn, S. T. AND SteEl, K. J. 1965. Manual for the identification of medical bacteria, 1st ed., London.

Cruickshank, R. 1965. Medical microbiology, 11 th ed., Edinburgh, p. 41.

Evans, N. M. 1968. The classification of aerobic diphtheroids from human skin. Br. $J$. Derm., 80, 81.

McLeod, J. W. AND GoRdon, J. 1922. Production of hydrogen peroxide by bacteria. Biochem. J., 16, 499. 
MARSH, P. D. 1975. In vitro studies of antagonism among human skin bacteria. Ph.D. thesis, University of London.

MARSH, P.D. AND SelwyN, S. 1977. Continuous-culture studies of interactions among human skin-commensal bacteria. J. med. Microbiol., 10, 261.

Miles, A. A., MisRa, S. S. AND IRwIN, J. O. 1938. The estimation of the bactericidal power of the blood. J. Hyg., Camb., 38, 732.

Sarkar, N. AND Paulus, H. 1972. Function of peptide antibiotics in sporulation. Nature, New Biol., 239, 228.

SELwYN, S. 1975. Natural antibiosis among skin bacteria as a primary defence against infection. Br. J. Derm., 93, 487.

SelwyN, S. AND Ellis, H. 1972. Skin bacteria and skin disinfection reconsidered. $\mathrm{Br}$. med. J., $1,136$.

Selwyn, S., Marsh, P. D. AND Sethna, T. N. 1976. In vitro and in vivo studies on antibiotics from skin Micrococcaceae. In Chemotherapy Proc. 9th int. Congr. Chemother., 1975), edited by J. D. Williams and A. M. Geddes, New York, vol. 5, p. 391. 